\title{
Analysis of Solar Radiation Data in Van, Turkey
}

\author{
İrfan Uçkan* \\ Department of Mechanical Engineering, Yuzuncu Yil University, Van, Turkey \\ *irfanuckan@yyu.edu.tr
}

Received: 18 June 2018

Accepted: 11 October 2018

DOI: $10.18466 /$ cbayarfbe. 434552

\begin{abstract}
This work has processed, analyzed and regulated the data comprising surface temperature, sunshine duration and global solar radiation for the period of 1993 to 2007 in Van $(38.28 \mathrm{oN}, 43.20 \mathrm{oE})$. Hourly, monthly and annual variations of solar radiation are calculated. Furthermore, the annual variations of sunshine duration, surface temperature and clearness index are also analyzed. Annual average maximum global solar radiation was seen in 2000 with $19.68 \mathrm{MJ} / \mathrm{m} 2$ day and the trend of yearly series of global solar radiation increases from 1993 to 2007 . The highest hourly and monthly values are $3260 \mathrm{~kJ} / \mathrm{m} 2 \mathrm{~h}$ and 28.72 $\mathrm{MJ} / \mathrm{m} 2$ day, respectively. Besides, daily monthly and annual of clearness index, hourly frequency distribution and sunshine duration are discussed and the solar radiation and the annual clearness index are correlated. Consequently, the Van region has a high solar energy potential and a high frequency of clear daylight.
\end{abstract}

Keywords: Solar radiation, Clearness index, Sunshine duration, Renewable energy.

\section{Introduction}

To evaluate the solar energy potential of a region, regional sun radiation needs to be known and calculated. One way to do this is to collect long-term solar radiation measurements. It is very important to have knowledge of the solar radiation of an area in terms of evaluating the conversion of solar radiation potential to thermal engineering, agricultural and electrical applications. This information is a prerequisite for solar energy conversion systems design, cost analysis and efficiency calculations. In addition, daily monthly and annual radiation values are very important in estimating the long-term performance of a solarpowered system.

In literature, many studies have been done on this topic because of large application area. The use of photovoltaic devices is suitable for rural areas to meet electricity need. It is also important to use these devices in the irrigation by pulling water from the well in agricultural areas where electricity is difficult to reach $[1,2]$. Solar energy systems can be used also for drying, water heating and thermal load analyses on buildings studies [3-6]. Most of efforts to define the solar radiation capacity of a particular site focus on estimating global solar radiation data [7] and many theoretical models have proposed. One of the common methods to estimate of solar energy potential of a place is artificial neural network [8-11]. It is available in various studies depending on the satellite data values [12-14]. In Turkey, there are several studies on solar energy modeling and estimating [15-16]. However, a few investigations on long term solar data have been evaluated for Turkey [17]

There is increasing interest in alternative energy sources such as solar and wind energy to meet future energy needs because of the uncertainties in fossil-based energy prices and fluctuations over time. Photovoltaic cells, solar cooling and heating can be an alternative to oil or electric energy based coal or natural gas for countries such as Turkey. VAN (Latitude $38.28^{\circ} \mathrm{N}$, Longitude $43.20^{\circ} \mathrm{E}$ ) is situated on the eastern of Turkey. This renewable energy can be used as an alternative source of energy instead of fossil-based other energy for this location. The Turkish government follows programs to encourage using of solar energy, including systematic monitoring and evaluation of technological developments as well as implementation of pilot models and appropriate technologies. VAN is one of the places that have been supported for the implementation of this pilot project.

For this reason, this article was conducted to help farmers, engineers and designers working in the solar energy field. In this study, long term measurement data of global solar radiation, surface temperature and sunshine duration was used to evaluate the potential of solar energy for Van province.

\section{Materials and Methods}

In this study, 15-year (long-term) monthly, hourly and daily average solar radiation data are given and monthly mean daily extraterrestrial radiation, $\mathrm{H}_{0}$, can be taken by [18]; 


$$
\begin{aligned}
& H_{o}=\frac{24 \times 3600 G_{s c}}{\pi}\left[1+0.033 \cos \left(\frac{360 n}{365}\right)\right] \\
& x\left[\cos (\Phi) \cos (\delta) \sin \left(w_{s}\right)\right) \\
& +((\pi w s) / 180) \sin (\Phi) \sin (\delta)]
\end{aligned}
$$

where $w_{s}$ is the sunset hour angle, in degrees, and it can be found from following equation,

$\cos w_{s}=-\tan \Phi \tan \delta$

and

$\Phi$ is the latitude of the location, the $G_{S c}$ is the solar constant $\left(1367 \mathrm{~W} / \mathrm{m}^{2}\right)$, the declination is $\delta$ and $n$ is the day of the year for each month.

$\delta=23.45 \sin \left[\frac{360}{365}(284+n)\right]$

It is important to calculate the average hourly extraterrestrial radiation to find other parameters.

$I_{o}=\frac{12 x 3600 G_{s c}}{\pi}\left[1+0.033 \cos \left(\frac{360 n}{365}\right)\right]$
$x\left[\begin{array}{c}\cos (\Phi) \cos (\delta)\left(\sin w_{2}-\sin w_{1}\right) \\ \left(\frac{\pi w_{s}}{180}\right) \sin (\Phi) \sin (\delta)\end{array}\right]$

where $w_{2}$ and $w_{1}$ are hour angles and $w_{2}$ is larger.

At the same time, the monthly average daily clearness index $K_{T}$;

$K_{T}=\frac{H}{H_{o}}$

Another important parameter is the monthly average hourly clearness index $\left(k_{T}\right)$. This parameter can be defined as:

$k_{T}=\frac{I}{I_{o}}$

\section{Results and Discussions}

Annual, monthly and daily global solar radiation data were evaluated between the years of 1993 and 2007 . Furthermore, the sunshine duration and the surface temperature values are presented. The annual monthly and hourly average variations of these values are calculated. Based on long term global solar radiation data, clearness index for monthly and daily is calculated.
For Van, the monthly average long-term global solar radiation change over a 15 -year period is shown in Figure1, and monthly average long-term global solar radiation levels are also shown in this figure. As seen in Figure 1, the highest monthly long-term average global solar radiation was observed at $28.72 \mathrm{MJ} / \mathrm{m}^{2}$ in June. The lowest global solar radiation for this time interval was calculated for December, although global solar radiation values in January and December were close each other to $10.12 \mathrm{MJ} / \mathrm{m}^{2}$ and $8.68 \mathrm{MJ} / \mathrm{m}^{2}$, respectively.

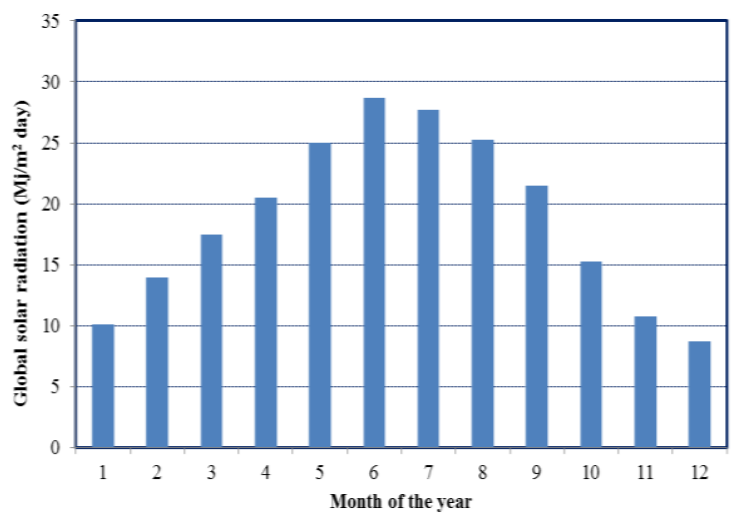

Figure 1. Variation of monthly average long term global solar radiation for a 15 year period from 1993 to 2007.

Clearness index is a parameter ranging from 0 to 1 , which is defined by dividing the amount of surface radiation to extraterrestrial radiation and helping to see the amount of the radiation coming to the earth. If the clearness index is 1 , it means that the light passing through the atmosphere will reach the earth without any reflection. This index can provide information about actual solar radiation when compared to the current solar radiation. It can have a low or high value under open sunny conditions and cloudy conditions and is dependent on the geographical coordinates of the calculated location. Figure 2 illustrates daily average clearness index variation for a fifteen year period for each day. It is observed that the daily clearness index varies between 0.47 and 0.77 . The highest and lowest value of daily clearness index is observed on September 10 and April 3, respectively. It is also seen that there are not large fluctuations for the daily clearness index during the average of years. Monthly average clearness index values are shown in Figure 3. The highest and lowest values of monthly clearness index for the long term period are calculated 0.70 in September and 0.59 in April. However, there is an interesting situation here, which is the lowest clearness index is observed in April for the long term period. This situation can be explained by clouds that impact during the spring months. It is seen that the maximum clearness index is not included in the summer months. It was observed that the clearness index was variable and the highest value was realized in September, which belongs to the autumn 
season. When the measured long-range clearness index is examined, the annual average value is calculated as 0.64 .

The annual average values of this parameter have been analyzed in Figure 4 in order to detect year-to-year variations. The values of it between the years of 1993 2000 increases firstly and this value decreases after the year of 2000. It is observed that the annual clearness index for the long term period varies between approximately 0.60 and 0.68 .

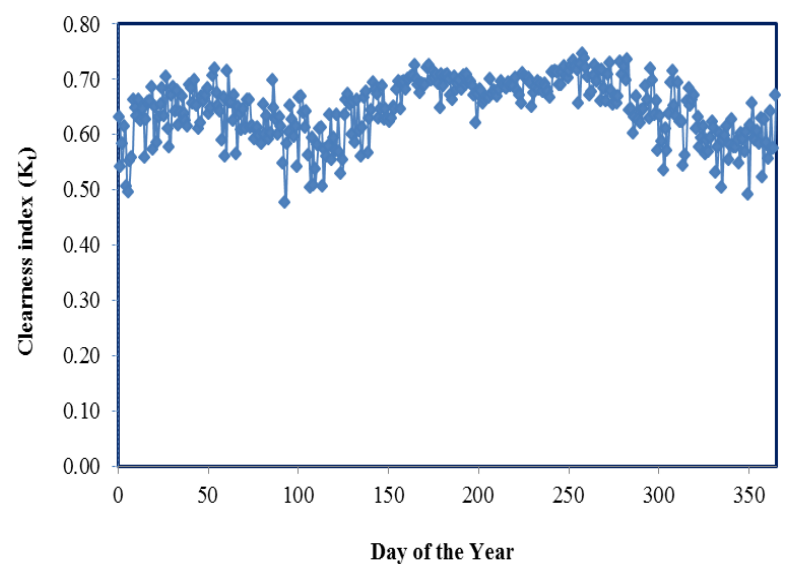

Figure 2. Daily average clearness index variation for a 15 year period from 1993 to 2007.

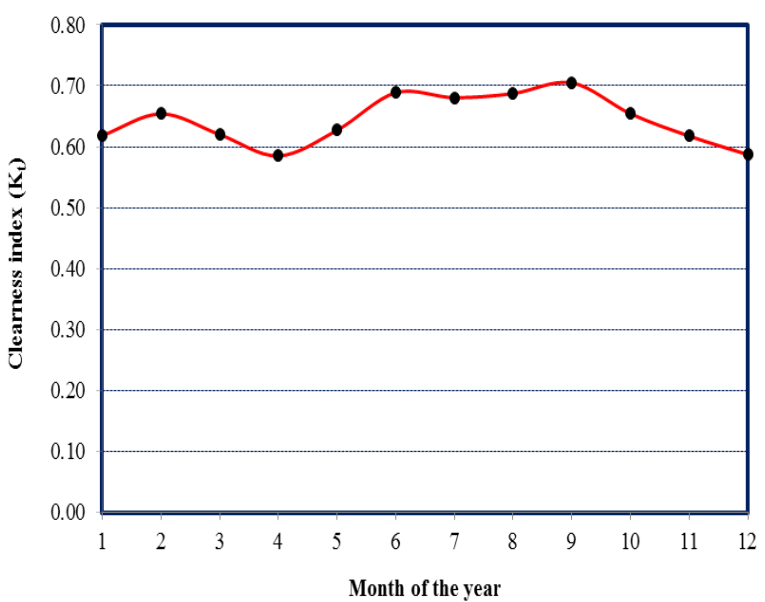

Figure 3. Variation of monthly average clearness index for long term period.

The highest and lowest annual values of the clearness index were calculated for the year of 2000 and 1993 with 0.677 and 0.60 , respectively. The region in which this study was conducted has divided four seasons and accordingly it is divided into different groups corresponding to these seasons for each month of the year. The distribution of the hourly measurement results of global solar radiation according to seasons such as summer, autumn, winter and spring is shown in Figure 5. In this figure, the hourly global solar radiation for the long term period is calculated. It can be seen that the highest value was observed at 12:00 o'clock when the solar radiation values are evaluated according to all seasons. In addition, when the distribution of the solar radiation in the day is taken into consideration, it takes a symmetrical value at noon and it starts to decrease after the afternoon. It is seen that the values measured in June are higher than the values measured in the other months. In this season the maximum global solar radiation arrives to approximately $3260 \mathrm{~kJ} / \mathrm{m}^{2} \mathrm{~h}$ in June. The minimum long term solar radiation values are obtained in the winter months and the minimum value is observed in December with $1500 \mathrm{~kJ} / \mathrm{m}^{2} \mathrm{~h}$. The seasonal global solar radiation reaches their peak values during summer (June-August) and low values during winter (December-February).

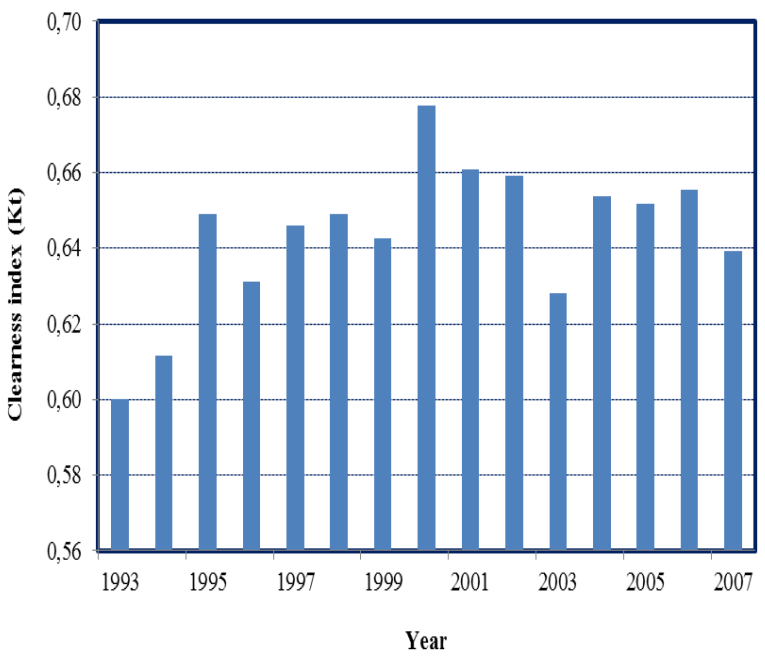

Figure 4. Variation of annual average clearness index at situation Van between the years of 1993 and 2007.

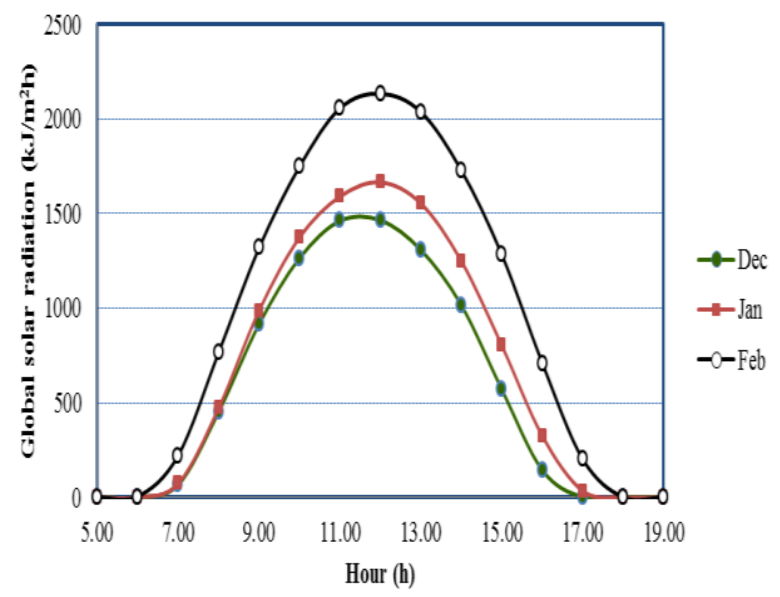

(a) 


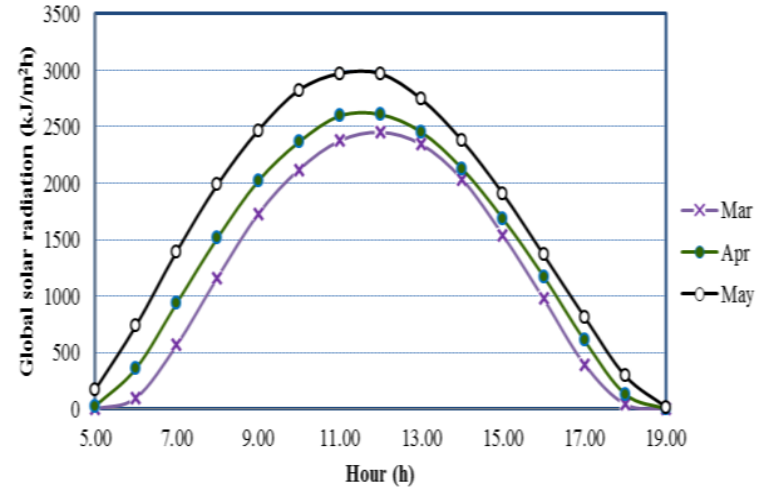

(b)

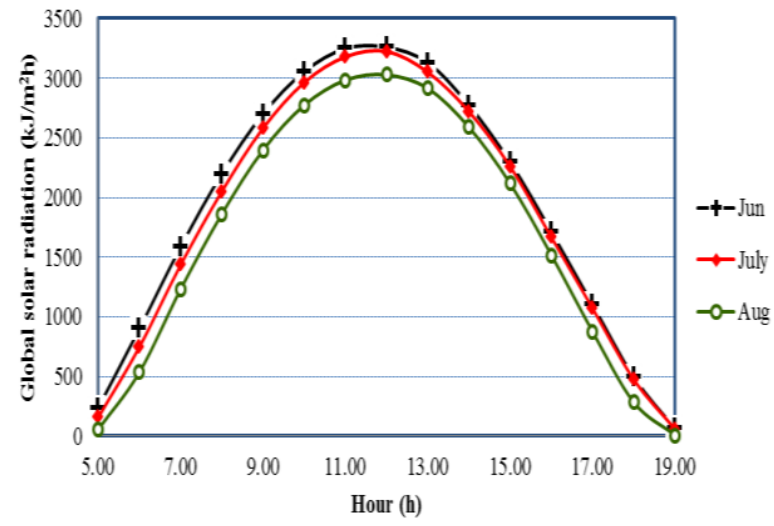

(c)

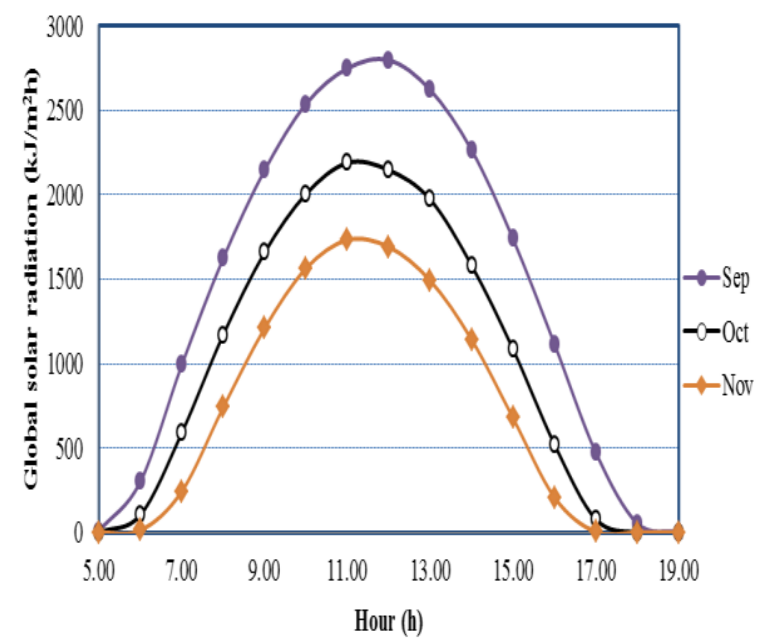

(d)

Figure 5. Distribution of hourly global solar radiation for winter (a), spring (b), summer (c) and autumn (d).

Figure 6 presents a percentage frequency distribution of the hourly clearness index for each season. The hourly clearness index varies from 0.24 to 0.79 throughout the long term period. It is clear from the figure that the highest hourly clearness index is observed during summer season with $0.65<\mathrm{K}_{\mathrm{t}}<0.75$ (\%70). The lowest frequency distribution is seen in winter season in which $0.65<\mathrm{K}_{\mathrm{t}}<0.75$ is \%30. This figures show that there is a high frequency of clear days $\left(K_{t}>0.60\right)$ throughout the year. It can be said that Van has large values of the clearness index and clear days and has small cloudy days.

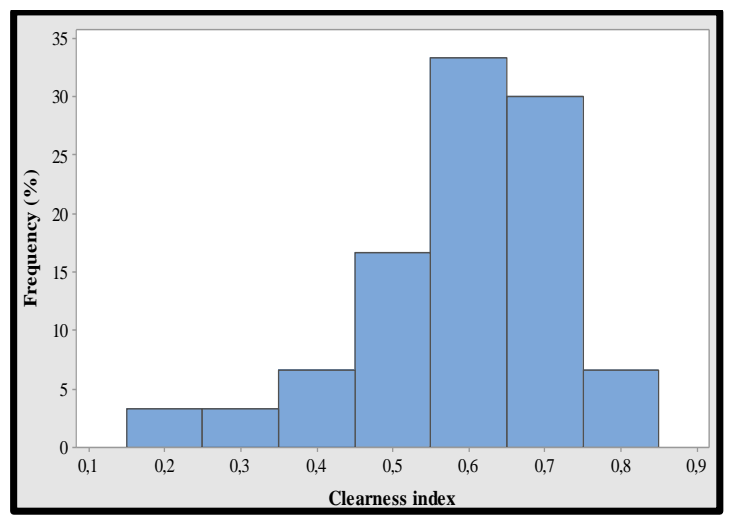

(a)

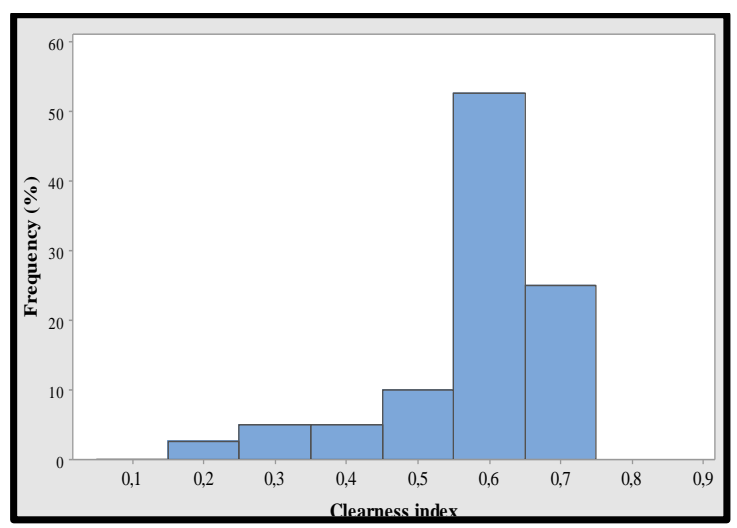

(b)

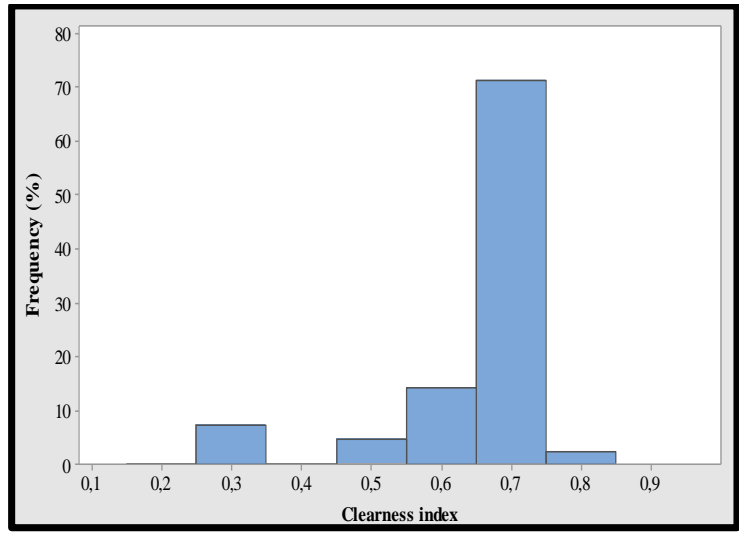

(c) 


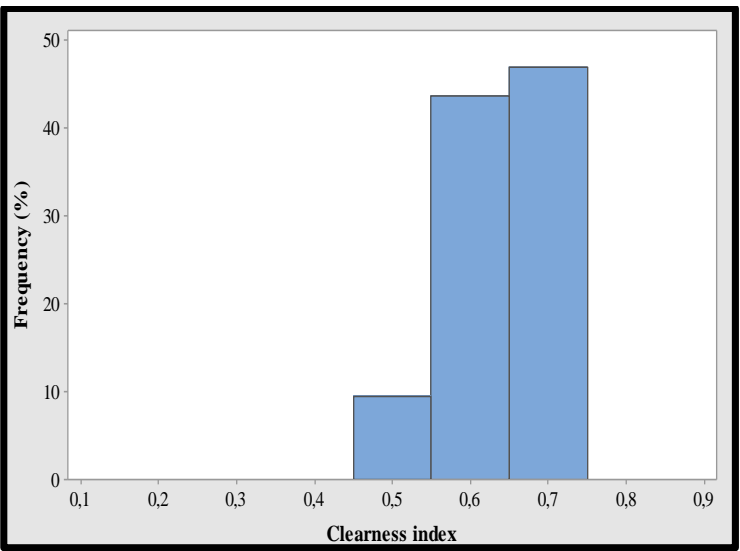

(d)

Figure 6. Histogram of percentage frequency distribution of the hourly clearness index for winter (a), spring (b), summer (c) and autumn (d).

Figure 7 shows multiple years variations of annual average global solar radiation for a fifteen year period from 1993 to 2007.

It is observed that a general upward trend started from 1993 and continued up to 2007. Firstly, global solar radiation tends to increase from 1993 to 2000. After the year of 2000 this value tends to decrease. The highest and lowest annual average value of global solar radiation in fifteen years are observed in the year of 2000 and 1993 with $19.68 \mathrm{MJ} / \mathrm{m}^{2}$ and $17.60 \mathrm{MJ} / \mathrm{m}^{2}$, respectively. This large value of solar energy encourages scientists, researchers and engineers to develop projects, thus, the use of fossil fuels can be reduced using such energy. Also, the annual average of global solar radiation data have been fitted using linear regression shown in Figure 7. In this figure, fifteen year-average global solar radiation have been calculated to determine variations and trends of the long term global solar radiation. It is observed in this figure that there is a general increase in the global solar radiation. This variation trend is observed in the other regions of Turkey [19].

Figure 8 illustrates variation of monthly mean, maximum and minimum values of surface temperature for the long term period for Van. As can be seen in this figure, the highest monthly maximum, mean and minimum values of temperature are observed on August with $28.3{ }^{\circ} \mathrm{C} 22.83{ }^{\circ} \mathrm{C}$ and $16.47{ }^{\circ} \mathrm{C}$, respectively. On the other hand monthly minimum value of temperature is $-5.7{ }^{\circ} \mathrm{C}$ on January. Comparison monthly mean global solar radiation with monthly mean surface temperature for the long term period is depicted in Figure 9. When the global solar radiation reaches to the highest value with $28.72 \mathrm{MJ} / \mathrm{m}^{2}$, the surface air temperature is $19.5^{\circ} \mathrm{C}$. This temperature is lower than that of August. Although the highest monthly mean temperature is recorded in August with $28.31{ }^{\circ} \mathrm{C}$, the highest monthly mean long term global solar radiation is observed in June with
$28.72 \mathrm{MJ} / \mathrm{m}^{2}$. This trend has also been observed by [20]. As can be seen from this figure, the monthly variation of the average surface temperature has the same trend curve as that of global solar radiation.

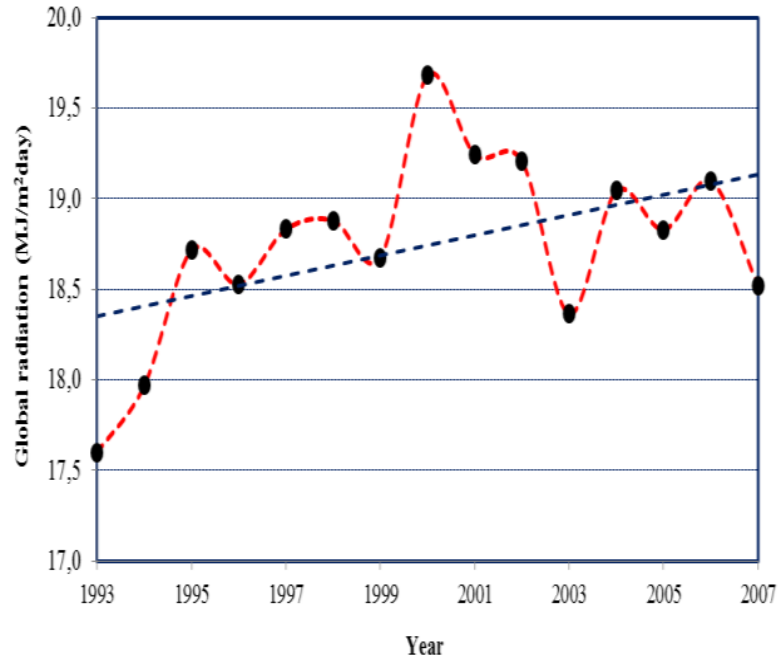

Figure 7. Multiple years variations of annual average of global solar radiation.

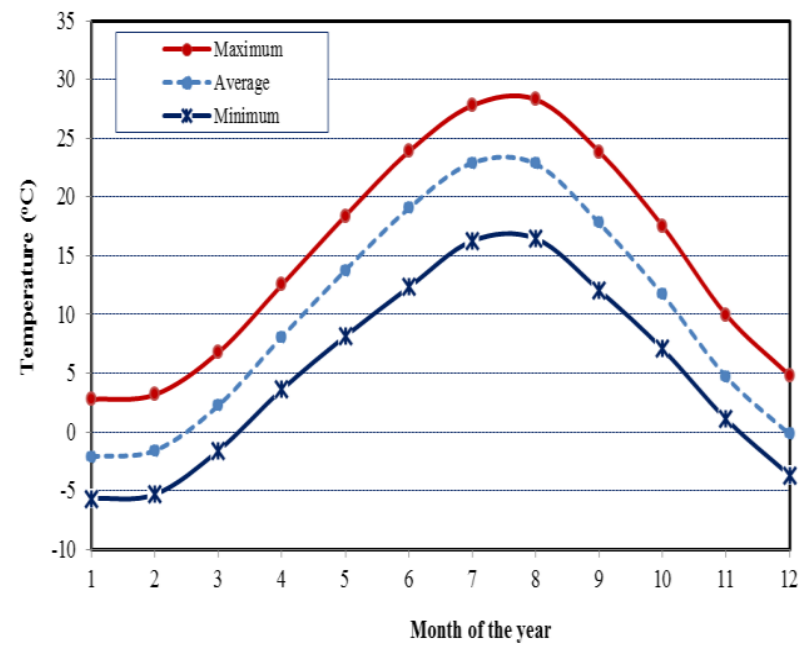

Figure 8. Variation of monthly mean, maximum and minimum values of temperature for the long term period.

Daily average of sunshine duration in Van during the year is illustrated in Figure 10. It is observed that the daily sunshine duration varies between $4 \mathrm{~h}$ and $13.38 \mathrm{~h}$. The highest value of daily sunshine duration is seen in $174^{\text {th }}$ day that corresponds to June. Higher sunshine durations are seen in summer, particularly throughout the months of June-August. The yearly average of long term sunshine duration is found as $3027 \mathrm{~h}$. Figure 11 illustrated to define the year-to-year variations of the annual average values of the sunshine duration. It was seen that there was not much difference in the 15 -year time span between 1993 and 2007. The maximum and minimum yearly sunshine duration was found in the year of 2000 and 2007 with $3203 \mathrm{~h}$ and $2735 \mathrm{~h}$, 
respectively. Figure 12 shows the variation of the clearness index with solar radiation. Also, the finding of this study has been reflected by the correlation. According to this correlation there is a linear fit between the clearness index and solar radiation. It is observed that Van has a high potential in terms of solar energy potential and has a good location for the use of this energy based on the temperature, clearness index, global solar radiation and sunshine duration.

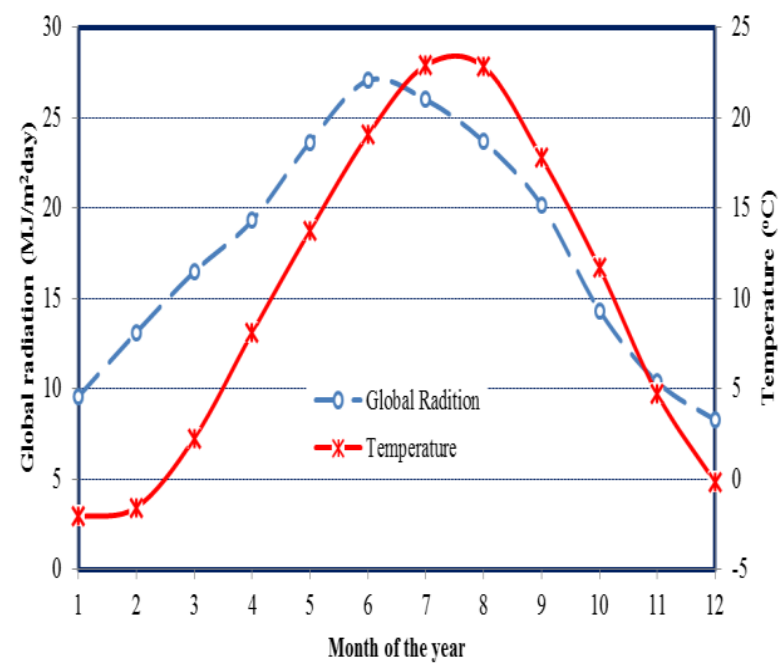

Figure 9. Comparison monthly mean global solar radiation with monthly mean surface temperature for the long term period.

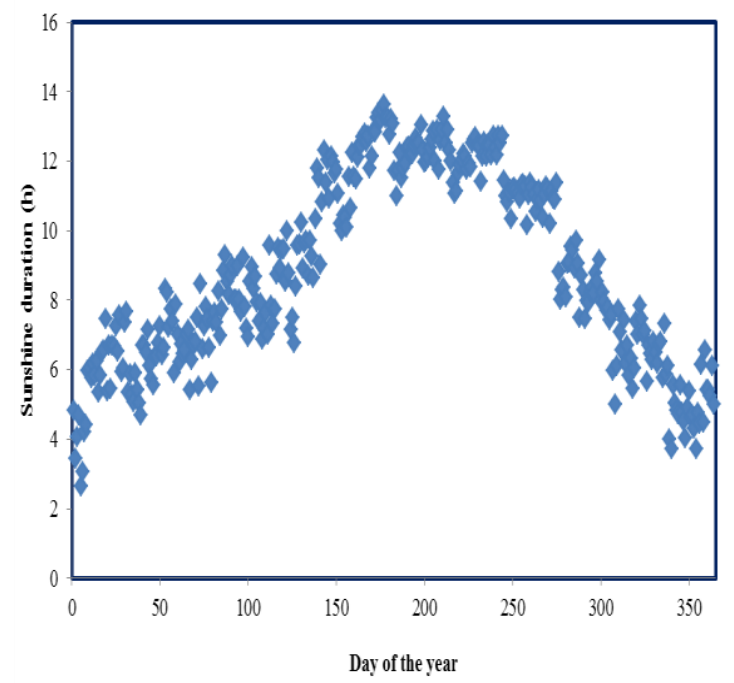

Figure 10. Daily average of sunshine duration in Van during the year.

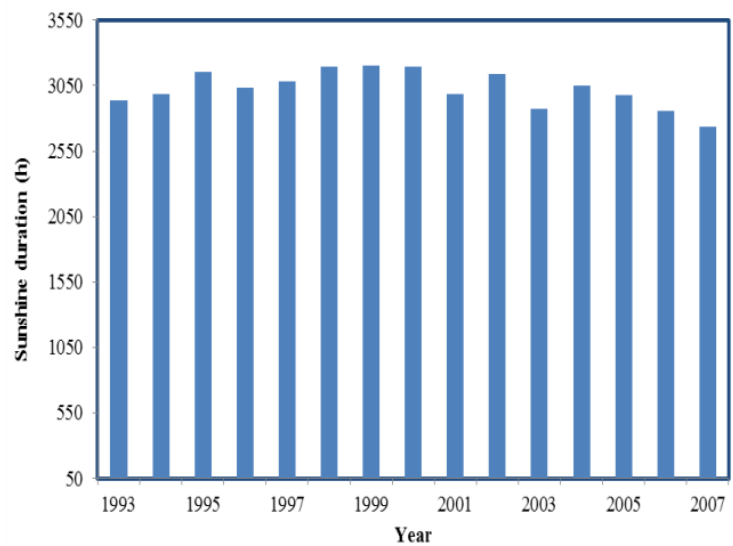

Figure 11. The annual average of the sunshine duration.

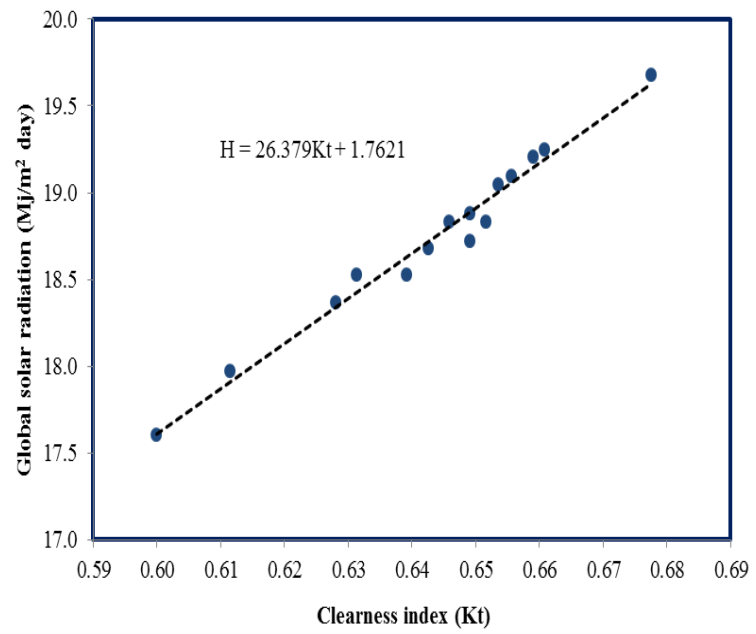

Figure 12. Correlation between monthly average global solar radiations with the corresponding values clearness index.

\section{Conclusion}

This study was conducted on the basis of the solar energy potential by using a certain interval data on horizontal surface of Van province that is located eastern of Turkey. Between 1993 and 2007, daily and hourly global solar radiation data, sunshine duration and surface temperature values are evaluated in this work. Annual, monthly and hourly average variations of these values are calculated. Based on long term global solar radiation data, clearness index for annual, monthly and daily is calculated. The purpose of this analysis is to assist designers and users in evaluating potential of solar energy applications of the Van location.

The main results that can be understood from this study are listed below.

- When the monthly average solar radiation values were examined, the highest radiation value was found $28.72 \mathrm{MJ} / \mathrm{m}^{2}$ in June and the lowest value was found $8.68 \mathrm{MJ} / \mathrm{m}^{2}$ in December.

- The daily clearness index for the long term period ranged from 0.47 and 0.77 and the monthly average 
clearness index various between 0.59 and 0.70 for 15 year period. Annual average of clearness index for the long term period is found as 0.64 and maximum annual clearness index is observed in the year of 2000.

- The clearness index frequency distribution indicates that the Van region is typically dominated by sunny days. The frequencies of cloudy days are small.

- This article illustrate the variation of solar radiation between the four seasons; winter, spring, summer and autumn. It is seen that the highest and lowest values of the hourly global radiation are observed during the summer season with $3260 \mathrm{~kJ} / \mathrm{m}^{2} \mathrm{~h}$ in June and winter seasons with $1500 \mathrm{~kJ} / \mathrm{m}^{2} \mathrm{~h}$ in December.

- There is a good correlation between the global solar radiation and the clearness index and a linear equation between the clearness index and solar radiation has been developed accordingly.

- The lowest and highest values of the average daily sunshine duration are recorded to be $4 \mathrm{~h}$ and $13.38 \mathrm{~h}$. The annual average of long term sunshine duration is found as $3027 \mathrm{~h}$

Finally, it is important to state that Van has a significant potential for solar energy generation.

\section{References}

1. Diaz, P, Peña, R. Muñoz, J, Arias, C.A, Sandoval, D, Field analysis of solar PV based collective systems for rural electrification, Energy, 2011, 36, 2509-2516.

2. Benghanem, M, Daffallah, K.O, Alamri, S.N, Joraid, A.A, Effect of pumping head on solar water pumping system, Energy Conversion and Management, 2014, 77, 334-339.

3. Helwa, N.H, Abdel Rehime, Z.S, Experimental study of the performance of solar dryers with pebble beds, Energy Sources, 2007, 19 (6), 579-591.

4. Chaturvedi, S.K, Gagrani, V.D, Abdel Salam, T.M, Solar-assisted heat pump - A sustainable system for low-temperature water heating applications,, Energy Conversion and Management, 2014 $77,550-557$

5. Ayompe, L.M, Duffy, A, Analysis of the thermal performance of a solar water heating system with flat plate collectors in a temperate climate, Applied Thermal Engineering, 2013, 58:447454.

6. Soussib, M, Balghouthia, M, Guizania, A, Energy performance analysis of a solar-cooled building in Tunisia: Passive strategies impact and improvement techniques, Energy and Building 2013, $67,374-386$

7. Şenkal, O, Şahin, M. Peştemalci, V, The Estimation of sola radiation for different time periods, Energy Sources, Part A Recovery Utilization and Environmental Effects, 2010, 32(13), 1176-1184.

8. Mohandes, M, Rehman, S, Halawani, T.O, Estimation of global solar radiation using artificial neural networks, Renewable Energy, 1998,14,179-184.
9. Sözen, A, Arcaklioğlu, E, Özalp, M, Estimation of solar potential in Turkey by artificial neural network s using meteorological and geographical data, Energy Conversion and Management, 2004, 45, 3033-3052.

10. Azeez, M.A, Artificial neural network estimation of global solar radiation using meteorological parameters in Gusau, Nigeria, Archives of Applied Science Research, 2011, 3(2), 586-595.

11. Hasni, A, Sehli, A, Draoui, B, Bassou, A, and Amieur, B, Estimating global solar radiation using artificial neural network and climate data in the south-western region of Algeria, Energy Procedia, 2012, 18, 531-537.

12. Hirunlabh, J, Sarachitti, R, Namprakai, P, Estimating solar radiation at the earth's surface from satellite data, Tammasart International Journal of Science and Technology, 1997, 1,69-79.

13. Janjai, S, Laksanaboonsong, J, Nunez, M, Thongsathitya, A, Development of a method for generating operational solar radiation maps from satellite data for a tropical environment, Solar Energy, 2005, 78,739-751.

14. Vignola, F, Harlan, P, Perez, R, Kmiecik, M, Analysis of satellite derived beam and global solar radiation data, Solar Energy, 2007, 81, 768-772.

15. Bakirci, K, Correlations for estimation of daily global solar radiation with hours of bright sunshine in Turkey, Energy, 2009, $34,485-501$.

16. Toğrul, I.T, Onat, E, A study for estimating solar radiation in Elaziğ using geographical and meteorological data, Energy Conversion and Management, 1999, 40, 1577-1584.

17. Bulut, $\mathrm{H}$, Büyükalaca, $\mathrm{O}$, Simple model for the generation of daily global solar-radiation data in Turkey, Applied Energy, 2007, $84,477-491$.

18. Duffie, J.A, Beckman, W.A, Solar Engineering of Therma Processes 3rd. ed, John Willey \& Sons, New York, 1991.

19. Aksoy, B, Solar radiation over Turkey and its analysis, International Journal of Remote Sensing, 2011, 32, 6261-6272.

20. Esen, $H$, Experimental energy and energy analysis of a doubleflow solar air heater having different obstacles on absorber plates, Building and Environment, 2008, 43, 1046-1054. 